\title{
Photocatalytic Degradation of Amoxicillin Using UV/Synthesized NiO from Pharmaceutical Wastewater
}

\author{
Davoud Balarak ${ }^{*}$ and Ferdos Kord Mostafapour \\ Department of Environmental Health, Health Promotion Research Center, School of Public Health, \\ Zahedan University of Medical Sciences, Zahedan, Iran
}

*Corresponding author:

email: dbalarak2@gmail.com

Received: March 10, 2018

Accepted: July 30, 2018

DOI: $10.22146 / \mathrm{ijc} .33837$

\begin{abstract}
The nano nickel(II) oxide (NiO) was synthesized by sol-gel method and used for degradation of Amoxicillin (AMO) from pharmaceutical wastewater. In this laboratory study, the effects of nanoparticle dose $(0.25-2 \mathrm{~g} / \mathrm{L})$, reaction time (10-120 min), initial antibiotic concentration $(25-200 \mathrm{mg} / \mathrm{L})$ and lamp power (15 W) on AMO removal efficiency were assessed in a batch photocatalytic reactor. Antibiotic concentration in output was measured by the spectrophotometer at the maximum wavelength of $280 \mathrm{~nm}$. The optimum nano $\mathrm{NiO}$ dose was obtained to be $0.2 \mathrm{~g} / \mathrm{L}$. In this study, the removal efficiency decreased with increasing the concentration of AMO. Under optimal conditions of concentration, the removal efficiency was 96\%. It was found that increasing the exposure time to UV increased the rate of AMO degradation in solution. The results also showed that the photo-degradation reaction approximately follows the pseudo-first-order kinetics with constant rates of 0.084, 0.074 and $0.046 \mathrm{~min}^{-1}$ for concentrations of 25, 50 and $100 \mathrm{mg} / \mathrm{L}$, respectively. On the basis of the obtained results, it can be concluded that UV/NiO photocatalytic process can efficiently remove AMO from pharmaceutical wastewater.
\end{abstract}

Keywords: photocatalytic degradation; amoxicillin; nano nickel(II) oxide; kinetics

\section{- INTRODUCTION}

In recent years, in many countries, especially in developing countries, concern and awareness of potential problems related to water pollution due to the occurrence of emerging contaminants are of growing interest among society [1-3]. These compounds are chemicals that originate from industrial, agricultural and human activities, very often as consumer products and byproducts used every day [4-5]. Many of these compounds are hardly biodegradable, for which much is yet unknown on their fate and potential impact on human health and environment, as well as on current water treatment technologies [6-7].

One of the newest chemicals is antibiotics. Pharmaceutical antibiotics are becoming increasingly problematic contaminants of water resources, particularly in surface and groundwater sources located around industrial and residential communities [8-9]. They enter water sources mostly through the discharge from pharmaceutical industries and municipal wastewater treatment plants [10]. Consumption of water contaminated with antibiotics can have several adverse effects on humans including acute and chronic toxicity [11]. Another critical concern regarding the antibiotics in water sources is the development of bacterial resistance to the medicinal treatment of bacterial infections [12-13].

Pharmaceutical chemicals are released by two main routes at water [14-15]. Pharmaceutical industry, which includes four different types of manufacturing processes, fermentation, chemical synthesis, extraction and formulating, often generates high strength wastewater with different character and quantity depending upon the used manufacturing processes and season [16]. The domestic route: most pharmaceutical chemicals will be dispensed or sold to the public, and after administration, these pharmaceuticals are excreted by the patients into wastewater in metabolized or non-metabolized forms [17]. 
Amoxicillin (AMO) is one of the most widely used b-lactam antibiotics used to treat human and animal infections [18-19]. Water containing this class of chemicals needs to be treated using an efficient process in order to protect human health and the environment against their adverse effects [20].

Some methods have been carried out for antibiotics removal from contaminated water. A wide range of methods containing physical, chemical and biological techniques have also performed to reduce their impact on the environment [21-22]. Although some chemical and biological methods such as ozonation, coagulation, flocculation, photocatalytic degradation, hypochlorite treatment, activated sludge, chemical precipitation, physical separation, biological degradation, aerobic/anaerobic digestion, advanced oxidation processes (AOPs) and electrochemical techniques are suitable in removing antibiotics [23-24]. Biodegradation may be one of the methods for the removal of antibiotics from sewage water. However, the limited studies on this topic showed that total biodegradation of some important antibiotics could not be accomplished and needs more detailed investigations [25-26].

The photocatalytic oxidation is one of the most promising technologies for eliminating the organic pollutants because it is highly efficient in mineralization and it can utilize the sunlight as energy source [27]. Among all the semiconductors used as the photocatalyst, $\mathrm{NiO}$ has proven to be most suitable for widespread environmental applications due to its high efficiency, non-toxicity, stability and economic advantages [28-29]. Most of the photocatalytic processes absorb the light at a wavelength shorter than $384 \mathrm{~nm}$. The ultraviolet (UV) light impinges on $\mathrm{NiO}$ surfaces, and thus generating electron-hole pairs which may result in the production of hydroxyl radicals $(\bullet \mathrm{OH})$ and perhydroxyl radicals $(\bullet \mathrm{OOH})[28]$. The objective of this research was to study the photocatalytic performance of the $\mathrm{UV} / \mathrm{NiO}$ process in the removal of AMO, taking into account the effects of different parameters such as solution catalyst dose, initial concentration of AMO, and contact time.
Table 1. Main properties of the AMO

\begin{tabular}{ll}
\hline Parameter & Character \\
\hline Molecular structure & \\
CAS number & $26787-78-0$ \\
Molecular formula & $\mathrm{C}_{16} \mathrm{H}_{19} \mathrm{~N}_{3} \mathrm{O}_{5} \mathrm{~S}$ \\
Molar mass & $365.4 \mathrm{~g} / \mathrm{mol}^{-1}$ \\
Solubility in water & $3430 \mathrm{mg} / \mathrm{L}$ at $20^{\circ} \mathrm{C}$ \\
Dissociation & $2.4(\mathrm{carboxyl}), 7.4$ (amine), and 9.6 \\
constant & $(\mathrm{phenol})$ \\
Henry's law & $2.73 \times 10^{-19}$ at $20{ }^{\circ} \mathrm{C}$ \\
constant &
\end{tabular}

\section{- EXPERIMENTAL SECTION}

\section{Materials}

Analytical grade AMO was obtained from Sigma Aldrich Co., and used as received; its characteristics are given in Table $1 . \mathrm{NaOH}, \mathrm{HCl}$ and nitric acid were supplied by Merck Chemical Company. All solutions were prepared using deionized water from a Milli Q system (Millipore, France). All glassware were made of the Pyrex and were washed with soap, nitric acid and rinsed with deionized water prior to use.

\section{Procedure}

\section{Preparation of nickel oxide}

The nickel oxide nanoparticles were prepared using the sol-gel process (30). First of all, $1.5 \mathrm{~g}$ $(0.0063 \mathrm{~mol})$ of was transferred to a $250 \mathrm{~mL}$ round bottom flask at room temperature and dissolved in $70 \mathrm{~mL}$ of absolute ethanol. The Solution was subjected to continuous stirring. In another beaker $0.5 \mathrm{~g}(0.0125 \mathrm{~mol})$ $\mathrm{NaOH}$ was dissolved in $100 \mathrm{~mL}$ of absolute ethanol. This Solution was added to $\mathrm{NiCl}_{2} \cdot 6 \mathrm{H}_{2} \mathrm{O}$ solution dropwise. The mixture was stirred at room temperature for $2 \mathrm{~h}$. Light green colored gel was formed after $2 \mathrm{~h}$. After $2 \mathrm{~h}$, the gel was filtered and washed with distilled water and then finally with ethanol. Light green colored precipitate was formed. The precipitate was oven dried at $100^{\circ} \mathrm{C}$ for 
$4 \mathrm{~h}$. Fine green powder was subjected to calcination at 290 ${ }^{\circ} \mathrm{C}$ for 30 min. Black colored nanopowder of $\mathrm{NiO}$ was prepared.

\section{Batch photocatalytic experiments and optimized conditions}

For the UV/photocatalyst process, the irradiation was performed in a $1 \mathrm{~L}$ photo-reactor with a low mercury lamp $15 \mathrm{~W}$. For the photodegradation of AMO, a solution containing the certain concentration of $\mathrm{AMO}$ and $\mathrm{NiO}$ was prepared and it was allowed to equilibrate for $30 \mathrm{~min}$ in the darkness. Then $100 \mathrm{~mL}$ of the prepared suspension was transferred to a $1 \mathrm{~L}$ Pyrex reactor. Having adjusted $\mathrm{pH}$ values of the suspension at the desired level using dilute $0.1 \mathrm{M} \mathrm{NaOH}$ and $\mathrm{HCl}$, the $\mathrm{pH}$ values were measured by pH meter (HANNA HI9811-5). Then, the lamp was switched on to initiate the reaction. During irradiation, the agitation was continued to have the homogenous suspension, and the suspension was sampled after an appropriate illumination time. The concentration of AMO in each degraded sample was determined by a UV spectrophotometer (DR-5000) at a wavelength of maximum absorbance $(280 \mathrm{~nm})$. The photodegradation efficiency $(\mathrm{X})$ is given by Eq. (1) (31-32):

$\mathrm{X}=\frac{\mathrm{C}_{0-} \mathrm{C}_{\mathrm{e}}}{\mathrm{C}_{0}}$

where $\mathrm{C}_{0}=$ initial concentration of $\mathrm{AMO}, \mathrm{C}=$ concentration of $A M O$ at time $t$.

\section{- RESULTS AND DISCUSSION}

\section{Characterization of Synthesized NiO}

Further analysis was conducted by XRD to confirm the phase of the synthesized $\mathrm{NiO}$ nanoparticles (Fig. 1). Before calcination, the sample was in an amorphous phase and the $\mathrm{NiO}$ phase was not observed. After calcination, crystalline phase presented a cubic structure, in which all diffraction lines of $\mathrm{NiO}$ were indexed to an ordered structure (ICSD 98-009-0203). Observed peaks at 37.72, $43.4,63.17,77.94$ and 79.61 show crystalline nature of $\mathrm{NiO}$ nanoparticles. In the amorphous phase, no significant change in the nickel phase occurred. Thus, no $\mathrm{NiO}$ phase existed. The crystalline phase existed after calcination, demonstrating that the metallic-nickel nanoparticles were readily oxidized to $\mathrm{NiO}$ nanoparticles.
The crystallite size of $\mathrm{NiO}$ nanoparticles was estimated by Debye-Scherrer equation by using Eq. (2): $\mathrm{D}=\frac{\mathrm{K} \delta}{\mathrm{T} \cos \theta}$

The average crystallite size of $\mathrm{NiO}$ nanoparticles was about $9.5 \mathrm{~nm}$.

At high magnification (50,000x), the $\mathrm{NiO}$ nanoparticles in the SEM image showed a spherical nanoparticle structure (Fig. 2). Also, the typical TEM image of $\mathrm{NiO}$ nanoparticles is shown in Fig. 3. There is a good agreement between the TEM and XRD results for the particle size. The average size of $\mathrm{NiO}$ nanoparticles, as measured by TEM, was found lower than $10 \mathrm{~nm}$.

\section{Effect of UV Light and NiO}

Photocatalytic degradation of AMO was investigated in the absence of $\mathrm{NiO}$ catalyst and UV light.

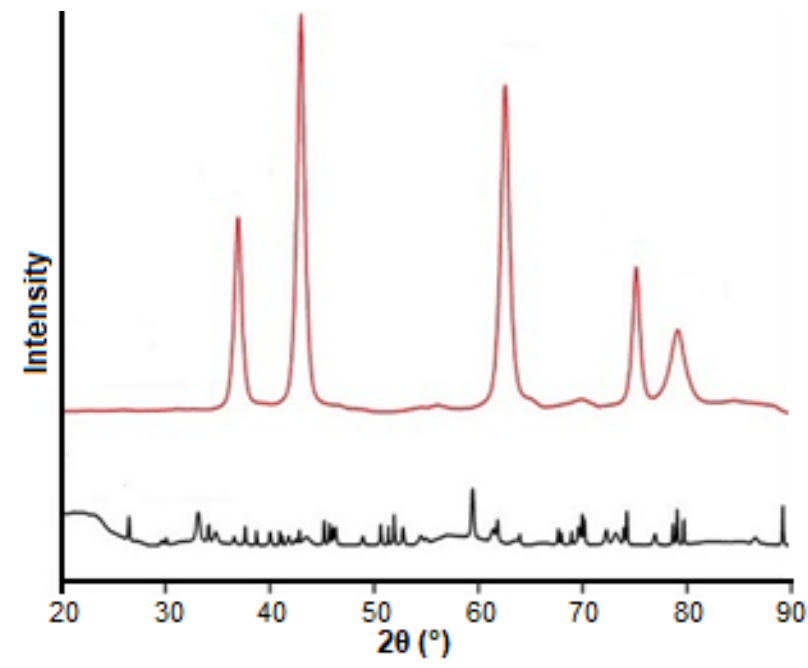

Fig 1. XRD pattern of the $\mathrm{NiO}$ nanoparticle

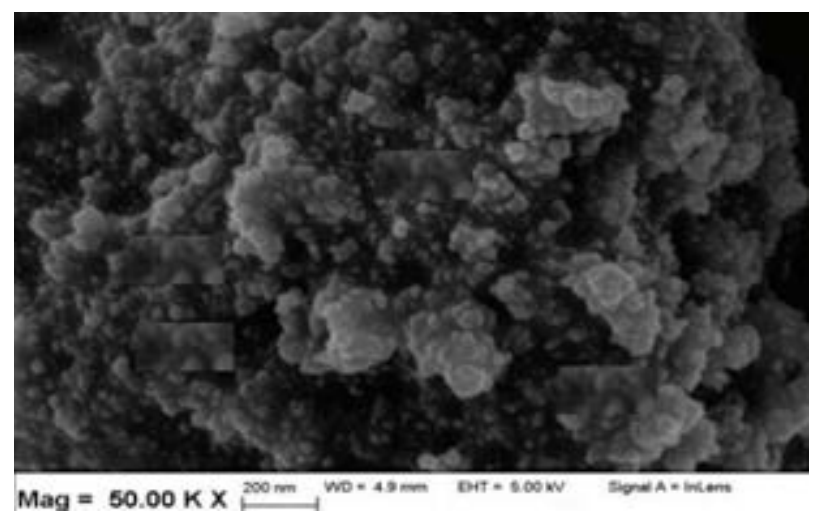

Fig 2. The SEM image of $\mathrm{NiO}$ nanoparticles prepared by the sol-gel method. 
The application of only nano $\mathrm{NiO}$ catalyst without UV light irradiation could not catalyze the degradation of the AMO antibiotics. It was observed that AMO degradation was not significant in the absence of laser or nano NiO. The results indicate that both the catalyst and light are essential for efficient degradation of AMO. The photo degradation of AMO in aqueous solution as a function of irradiation time in the presence of nano-structured $\mathrm{NiO}$ is shown in Fig. 4.

\section{Effect of NiO Dose}

Fig. 5 represents the photocatalytic degradation processes of $\mathrm{AMO}$ at different mass of $\mathrm{NiO}$. The photocatalytic removal of AMO gradually increases as the masses of $\mathrm{NiO}$ increases due to increasing the active site on the catalyst surface until reaching the optimum photocatalytic dose of $0.2 \mathrm{~g} / \mathrm{L}$, and then gradually decreases [33-34]. When the mass of $\mathrm{NiO}$ is equal to $0.2 \mathrm{~g} / \mathrm{L}$, the semiconductor $\mathrm{NiO}$ can provide the highest absorption of light. The decrease in the efficiency of photocatalytic degradation process at the masses of $\mathrm{NiO}$ higher than $0.2 \mathrm{~g} / \mathrm{L}$ due to the light absorption will be limited only to the first layers of AMO and the other layers of solution do not receive light photons [35]. Moreover, light scattering at high $\mathrm{NiO}$ loading is led to decrease the photon intensity; so that the light absorption is only occurred through the first layers of solution and reaching the lights

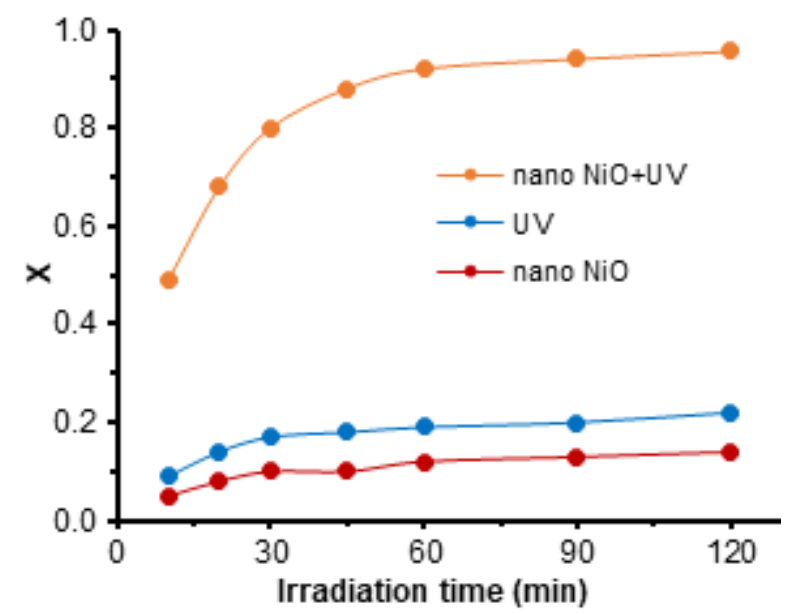

Fig 4. Effect of UV light and $\mathrm{NiO}$ on photocatalytic degradation of AMO $\left(\mathrm{C}_{0}=25 \mathrm{mg} / \mathrm{L}, \mathrm{NiO}=0.2 \mathrm{~g} / \mathrm{L}, \mathrm{pH}\right.$ neutral) to other layers is prevented. This brings the decreasing the AMO photo-degradation efficiency [36]. The kinetic results are plotted in Fig. 6 which shows that the rate constant of reaction generally increases with increase of photocatalyst concentration.

\section{Effect of Initial AMO Concentration}

The effect of initial AMO concentration on photodegradation efficiency is shown in Fig. 7. It was observed that the photo-degradation conversion of AMO decreases with an increase in the initial concentration of AMO. The presumed reason is that when the initial concentration of AMO is increased, more and more AMO molecules are adsorbed on the

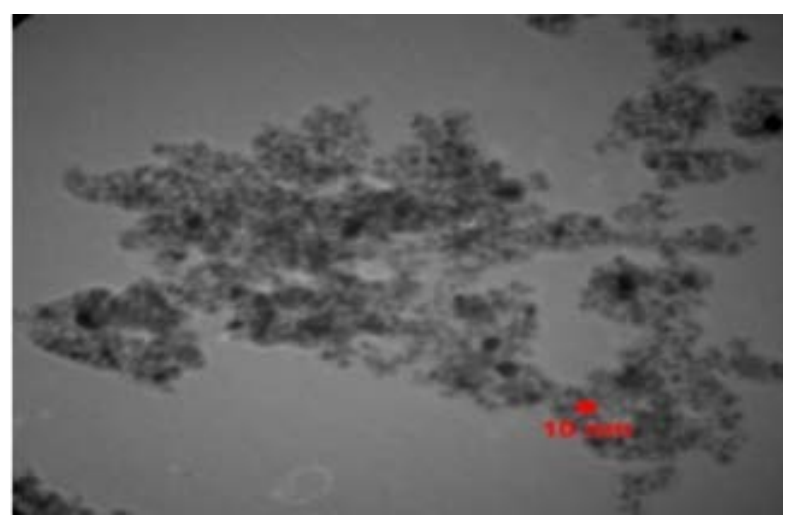

Fig 3. TEM micrograph of $\mathrm{NiO}$ nanoparticles prepared by sol-gel method

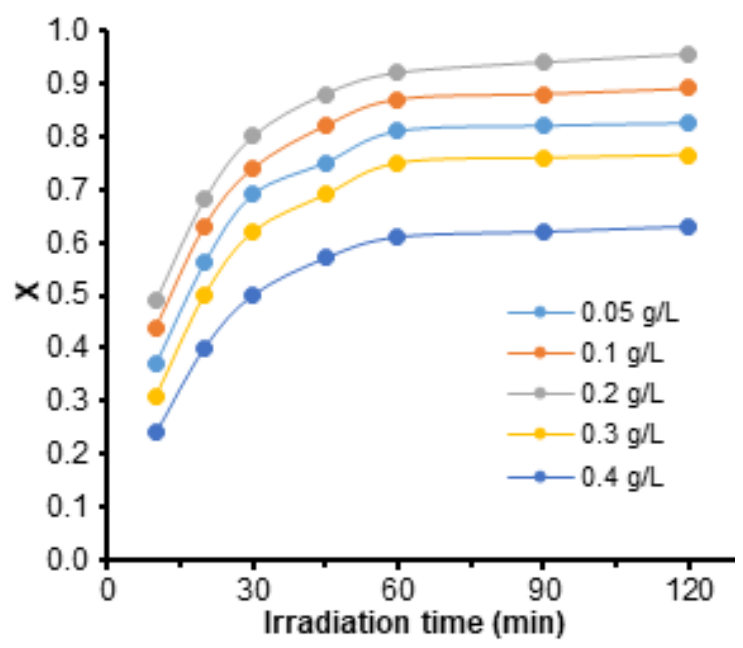

Fig 5. Effect dose on Photocatalytic degradation of AMO $\left(\mathrm{C}_{0}=25 \mathrm{mg} / \mathrm{L}, \mathrm{pH}\right.$ neutral, Temp: $\left.28^{\circ} \mathrm{C}\right)$ 


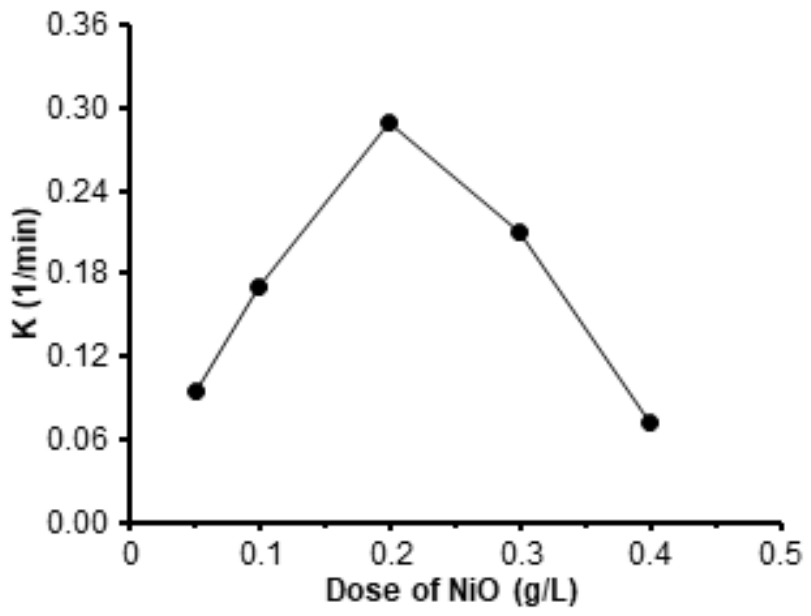

Fig 6. Effect of dose of $\mathrm{NiO}$ on rate constant (K)

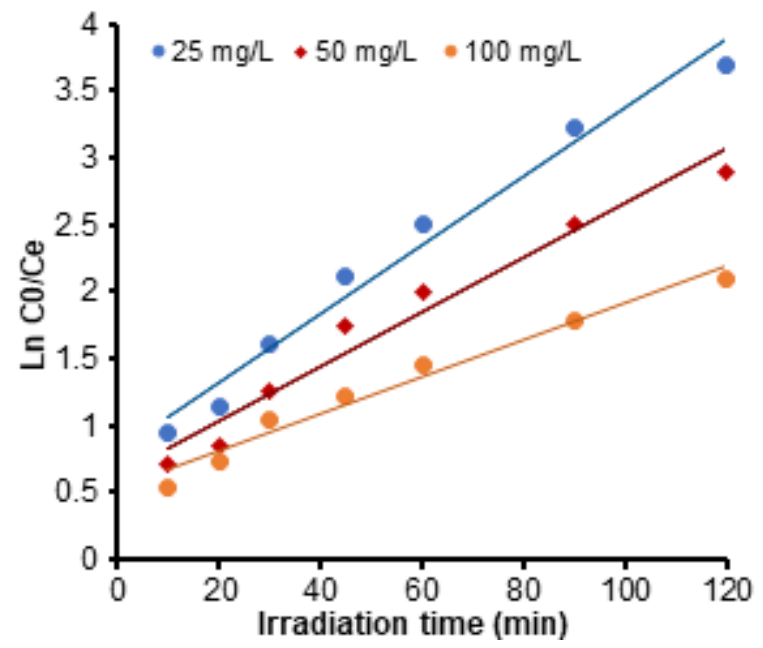

Fig 8. Kinetics of photocatalytic degradation on removal AMO $(\mathrm{NiO}$ dosage $=0.2 \mathrm{~g} / \mathrm{L}, \mathrm{pH}$ neutral, Temperature: $\left.28^{\circ} \mathrm{C}\right)$

surface of $\mathrm{NiO}$ [37-38]. The large amount of adsorbed AMO is thought to have an inhibitive effect on the reaction of AMO molecules with photogenerated holes or hydroxyl radicals, because of the lack of any direct contact between them [39]. Once the concentration of AMO is increased, the AMO molecules will also absorb the light making the photons could not reach the photocatalyst surface, thus the photo-degradation efficiency decreases [35].

\section{Kinetics of Photocatalytic Degradation of AMO}

It has been agreed that the expression for the rate

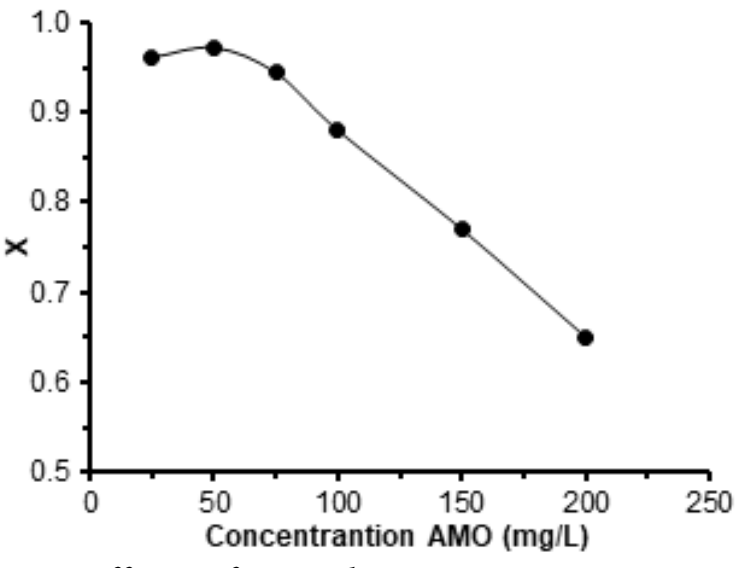

Fig 7. Effect of initial AMO concentration on photodegradation efficiency (catalyst dosage $=0.2 \mathrm{~g} / \mathrm{L}$, $\mathrm{pH}$ neutral, Temperature: $28^{\circ} \mathrm{C}$ )

of degradation of $\mathrm{AMO}$ with irradiated $\mathrm{NiO}$ follows the Langmuir-Hinshelwood (L-H) law or pseudo-firstorder of heterogeneous photocatalytic reactions [28]. In the kinetic equation of $\mathrm{L}-\mathrm{H}$, the relationship between concentration $(\mathrm{C})$ and time $(\mathrm{t})$ is as follows [40]:

$\mathrm{KC}=\frac{-\mathrm{d}_{\mathrm{C}}}{\mathrm{d}_{\mathrm{t}}}$

The integral equation is as follows [41-43]:

$\mathrm{KC}=\operatorname{Ln}\left(\frac{\mathrm{C}_{0}}{\mathrm{C}}\right)$

where $\mathrm{K}$ is the pseudo-first-order rate constant (that is affected by AMO concentration), and $t$, is the contact time. The plot of $\operatorname{Ln}\left(\mathrm{C}_{0} / \mathrm{C}_{\mathrm{e}}\right)$ versus the time provides a straight line, the slope of which upon linear regression equals the pseudo-first order rate constant $\mathrm{k}$. The linear plot of $\operatorname{Ln}\left(\mathrm{C}_{0} / \mathrm{C}_{\mathrm{e}}\right)$ versus time for model is shown in Fig. 8. The linear plot suggests that the photodegradation reaction approximately follows the pseudo-first-order kinetics with rate coefficient of $0.084,0.074$ and 0.046 $\mathrm{min}^{-1}$ for concentrations 25, 50 and $100 \mathrm{mg} / \mathrm{L}$ respectively. Also, the regression coefficients $\left(R^{2}\right)$ for the studied concentrations of AMO were equal to 0.981, 0.989 and 0.994 respectively. These results prove that the sorption data fitted well to the L-H model.

\section{- CONCLUSION}

The results of our study showed that $\mathrm{UV} / \mathrm{NiO}$ process could be efficiently used to degrade the AMO 
antibiotics. Photodegradation efficiency of AMO was small when photolysis was carried out in the absence of $\mathrm{NiO}$ and negligible in the absence of the UV light. The results indicated that the degree of degradation of AMO were obviously affected by the initial AMO concentration, contact time and the amount of $\mathrm{NiO}$. The result showed that the optimal amount of photocatalyst was $0.2 \mathrm{~g} / \mathrm{L}$, with AMO concentration of $25 \mathrm{mg} / \mathrm{L}$.

\section{- REFERENCES}

[1] Balarak, D., Azarpira, H., and Mostafapour, F.K., 2016, Thermodynamics of removal of cadmium by adsorption on Barley husk biomass, Der Pharma Chemica, 8 (10), 243-247.

[2] Diyanati, R.A., Yousefi, Z.A., and Cherati, J.Y., 2013, Investigating phenol absorption from aqueous solution by dried azolla, J. Mazand. Univ. Med. Sci., 22 (2), 13-21.

[3] Balarak, D., Mostafapour, F.K., and Joghataei, A., 2016, Adsorption of Acid Blue 225 dye by multi walled carbon nanotubes: Determination of equilibrium and kinetics parameters, Der Pharma Chemica, 8 (8), 138-145.

[4] Diyanati, R.A., Yousefi, Z., and Cherati, J.Y., 2013, The ability of azolla and lemna minor biomass for adsorption of phenol from aqueous solutions, $J$. Mazand. Univ. Med. Sci., 23 (106), 141-146.

[5] Peng, X., Hu, F., Dai, H., Xiong, Q., and Hu, C., 2016, Study of the adsorption mechanism of ciprofloxacin antibiotics onto graphitic ordered mesoporous carbons, J. Taiwan Inst. Chem. Eng., 65, $472-481$.

[6] Kansal, S.K., Kaur, N., and Singh, S., 2009, Photocatalytic degradation of two commercial reactive dyes in aqueous phase using nanophoto catalysts, Nanoscale Res. Lett., 4 (7), 709-16.

[7] Liu, W.F., Xie, H.J., Zhang, J., and Zhang, C.L., 2012, Sorption removal of cephalexin by $\mathrm{HNO}_{3}$ and $\mathrm{H}_{2} \mathrm{O}_{2}$ oxidized activated carbons, Sci. China Chem., 55 (9), 1959-1967.

[8] Liu, H., Liu, W., Zhang, J., Zhang, C., Ren, L., and Li, Y., 2011, Removal of cephalexin from aqueous solution by original and $\mathrm{Cu}(\mathrm{II}) / \mathrm{Fe}(\mathrm{III})$ impregnated activated carbons developed from lotus stalks kinetics and equilibrium studies, J. Hazard. Mater., 185 (2-3), 1528-1535.

[9] Garoma, T., Umamaheshwar, S.K., and Mumper, A., 2010, Removal of sulfadiazine, sulfamethizole, sulfamethoxazole, and sulfathiazole from aqueous solution by ozonation, Chemosphere, 79 (8), 814820.

[10] Balarak, D., Azarpira, H., and Mostafapour, F.K., 2016, Study of the Adsorption Mechanisms of Cephalexin on to Azolla filiculoides, Der Pharma Chemica, 8 (10), 114-121.

[11] Amini, M., Khanavi, M., and Shafiee, A., 2004, Simple high-performance liquid chromatographic method for determination of ciprofloxacin in human plasma, Iran. J. Pharm. Res., 3 (2), 99-101.

[12] Azarpira, H., Mahdavi, Y., and Khaleghi, O., 2016, Thermodynamic studies on the removal of metronidazole antibiotic by multi-walled carbon nanotubes, Der Pharmacia Lettre, 8 (11), 107-113.

[13] Fakhri, A., and Adami, S., 2014, Adsorption and thermodynamic study of Cephalosporins antibiotics from aqueous solution onto $\mathrm{MgO}$ nanoparticles, $J$. Taiwan Ins. Chem. Eng., 45 (3), 1001-1006.

[14] Carabineiro, S.A.C., Thavorn-Amornsri, T., Pereira, M.F.R., and Figueiredo, J.L., 2011, Adsorption of ciprofloxacin on surface modified carbon materials, Water Res., 45 (15), 4583-4591.

[15] Azarpira, H., and Balarak, D., 2016, Rice husk as a biosorbent for antibiotic metronidazole removal: Isotherm studies and model validation, Int. J. ChemTech Res., 9 (7), 566-573.

[16] Choi, K.J., Kim, S.G., and Kim, S.H., 2008, Removal of antibiotics by coagulation and granular activated carbon filtration, J. Hazard. Mater., 151 (1), 38-43.

[17] Hu, L., Flanders, P.M., Miller, P.L., and Strathmann, T.J., 2007, Oxidation of sulfamethoxazole and related antimicrobial agents by $\mathrm{TiO}_{2}$ photocatalysis, Water. Res., 41 (12), 2612-2626.

[18] Yu, F., Li, Y., Han, S., and Ma, J., 2016, Adsorptive removal of antibiotics from aqueous solution using carbon materials, Chemosphere, 153, 365-385. 
[19] Balarak, D., Mostafapour, F.K., Bazrafshan, E., and Saleh, T.A., 2017, Studies on the adsorption of amoxicillin on multi-wall carbon nanotubes, Water Sci. Technol., 75 (7-8), 1599-1606.

[20] Sakthivel, S., Neppolian, B., Shankar, M.V., Arabindoo, B., Palanichamy, M., and Murugesan, V., 2003, Solar photo-catalytic degradation of azo dye: Comparison of photocatalytic efficiency of $\mathrm{ZnO}$ and $\mathrm{TiO}_{2}$, Sol. Energy Mater. Sol. Cells, 77 (1), 65-82.

[21] Rostamian, R., and Behnejad, H., 2016, A comparative adsorption study of sulfamethoxazole onto graphene and graphene oxide nanosheets through equilibrium, kinetic and thermodynamic modeling, Process Saf. Environ. Prot., 102, 20-29.

[22] Gulkowska, A., Leung, H.W., So, M.K., Taniyasu, S., Yamashita, N., Yeung, L.W.Y., Richardson, B.J., Lei, A.P., Giesy, J.P., and Lam, P.K.S., 2008, Removal of antibiotics from wastewater by sewage treatment facilities in Hong Kong and Shenzhen, China, Water Res., 42 (1-2), 395-403.

[23] Balarak, D., and Joghataei A., 2016, Biosorption of phenol using dried rice husk biomass: Kinetic and equilibrium studies, Der Pharma Chemica, 8 (6), 96103.

[24] Balarak, D., Mahdavi, Y., Bazrafshan, E., Mahvi, A.H., and Esfandyari, Y., 2016, Adsorption of fluoride from aqueous solutions by carbon nanotubes: Determination of equilibrium, kinetic and thermo dynamic parameters, Flouride, 49 (1), 35-42.

[25] Balarak, D., 2016, Kinetics, isotherm and thermo dynamics studies on bisphenol a adsorption using barley husk, Int. J. ChemTech Res., 9 (5), 681-690.

[26] An, T., Yang, H., Li, G., Song, W., Cooper, W.J., and Nie, X., 2010, Kinetics and mechanism of advanced oxidation processes (AOPs) in degradation of ciprofloxacin in water, Appl. Catal., B, 94 (3-4), 288294.

[27] Sultana, S., Ramabadran, S., and Swathi, P.R., 2015, Photocatalytic degradation of azo dye using ferric oxide nanoparticle, Intl. J. ChemTech Res., 8 (3), 1243-1247.

[28] Muruganandham, M., and Swaminathan, M., 2006, $\mathrm{TiO}_{2}$-UV photo-catalytic oxidation of Reactive
Yellow 14: Effect of operational parameters, $J$. Hazard. Mater., 135 (1-3), 78-86.

[29] Fairooz, N.Y., 2016, Evaluation of new couple $\mathrm{Nb}_{2} \mathrm{O}_{5} / \mathrm{Sb}_{2} \mathrm{O}_{3}$ oxide for photocatalytic degradation of orange G dye, Int. J. ChemTech Res., 9 (3), 456461.

[30] Hayat, K., Gondal, M.A., Khaled, M.M., Ahmed, S., and Shemsi, A.M., 2011, Nano ZnO synthesis by modified sol gel method and its application in heterogeneous photocatalytic removal of phenol from water, Appl. Catal., A, 393 (1-2), 122-129.

[31] Balarak, D., and Azarpira, H., 2016, Biosorption of Acid Orang 7 using dried Cyperusrotundus: Isotherm studies and error functions, Int. J. ChemTech Res., 9 (9), 543-549.

[32] Azarpira, H., Mahdavi, Y., and Balarak D., 2016, Removal of Cd(II) by adsorption on agricultural waste biomass, Der Pharma Chemica, 8 (12), 61-67.

[33] Balarak, D., Mostafapour, F.K., and Azarpira, H., 2016, Adsorption isotherm studies of tetracycline antibiotics from aqueous solutions by maize stalks as a cheap biosorbent, Int. J. Pharm. Technol., 8 (3), 16664-16675.

[34] Fan, J., Hu, X., Xie, Z., Zhang, K., and Wang, J., 2012, Photocatalytic degradation of azo dye by novel Bi-based photocatalyst $\mathrm{Bi}_{4} \mathrm{TaO}_{8} \mathrm{I}$ under visible-light irradiation, Chem. Eng. J., 179, 44-51.

[35] Asahi, R., Morikawa, T., Ohwaki, T., Aoki, K., and Taga, Y., 2011, Visible-light photocatalysis in nitrogen-doped titanium oxides, Science, 293 (5528), 269-271.

[36] Vaiano, V., Sacco, O., Sannino, D., and Ciambelli, P., 2015, Photocatalytic removal of spiramycin from wastewater under visible light with $\mathrm{N}$-doped $\mathrm{TiO}_{2}$ photocatalysts, Chem. Eng. J., 261, 3-9.

[37] Balarak, D., Joghataei, A., Azarpira, H., and Mostafapour, F.K., 2016, Isotherms and thermodynamics of $\mathrm{Cd}(\mathrm{II})$ ion removal by adsorption onto Azolla filiculoides, Int. J. Pharm. Technol., 8 (3), 15780-15788.

[38] Anandan, S., Kathiravan, K., Murugesan, V., and Ikuma, Y., 2009, Anionic $\left(\mathrm{IO}_{3}^{-}\right)$non-metal doped $\mathrm{TiO}_{2}$ nanoparticles for the photocatalytic 
degradation of hazardous pollutant in water, Catal. Commun., 10 (6), 1014-1019.

[39] Sahel, K., Perol, N., Chermette, H., Bordes, C., Derriche, Z., and Guillard, C., 2007, Photocatalytic decolorization of Remazol Black 5 (RB5) and Procion Red MX-5B-isotherm of adsorption kinetic of decolorization and mineralization, Appl. Catal., B, 77 (1-2), 100-109.

[40] Balarak, D., Bazrafshan, E., Mahdavi, Y., Lalhmunsiama, and Lee, S.M., 2017, Kinetic, isotherms and thermodynamic studies in the removal of 2-chlorophenol from aqueous solution using modified rice straw, Desalin. Water Treat., 63, 203211.
[41] Zhu, C.M., Wang, L.Y., Kong, L.R., Yang, X., Wang, L., Zheng, S., Chen, F., MaiZhi, F., and Zong, H., 2000, Photocatalytic degradation of azo dyes by supported $\mathrm{TiO}_{2}+\mathrm{UV}$ in aqueous solution, Chemosphere, 41 (3), 303-309.

[42] Balarak, D., Mahdavi, Y., Bazrafshan, E., and Mahvi, A.H., 2016, Kinetic, isotherms and thermodynamic modeling for adsorption of acid blue 92 from aqueous solution by modified Azolla filiculoides, Fresenius Environ. Bull., 25 (5), 13211330.

[43] Zhang, L., Song, X., Liu, X., Yang, L., and Pan, F., 2011, Studies on the removal of tetracycline by multi-walled carbon nanotubes, Chem. Eng. J., 178, 26-33. 